\title{
画像による瞬目計測と居眠り検知への応用
}

\author{
正会員 中 野 倫 明 $^{\dagger}$, 杉山和 彦 ${ }^{\dagger}$, \\ 水 野 守 倫 ${ }^{\dagger}$ 正会員 山本 新 ${ }^{\dagger}$
}

\section{Blink Measurement by Image Processing and Application to Detection of Driver's Drowsiness}

\author{
Tomoaki Nakano $^{\dagger}$, Kazuhiko Sugiyama ${ }^{\dagger}$, Morimichi Mizuno $^{\dagger}$ \\ and Shin Yamamoto ${ }^{\dagger}$
}

\begin{abstract}
Many traffic accidents are caused by drowsiness while driving. The purpose of this research is to detect a driver's blinking using facial images obtained by a TV camera and to estimate the driver's arousal level to prevent the occurrence of an accident due to drowsiness. This report presents the method used to obtain the facial images, which are not affected much by the change of the ambient light by day and by night owing to the infrared light sources. This paper also describes the method for extracting the blinks and measuring the blinking durations, which are not influenced very much by individual differences in eye shape. Furthermore, we experiment with the relation between blinking durations and arousal levels as compared with vehicle deviation from the lane and driver's answer to the question about drowsiness. We also examine a method for estimating arousal level which reflects individual characteristics.
\end{abstract}

\section{1. ま え がき}

ここ数年, ヒューマンインタフェースやヒューマン コミュニケーションなど「人間の立場に立った物づく り」が重要視され ${ }^{1)}$, 人間の生理・心理状態あるいは 意図を反映した機器が開発されようとしている。これ に伴って, 人間の感覚・知覚などの生理や認知・感性 に踏み込んだ心理に関する研究が盛んになってきてお り, 様々な人間の感覚や挙動にかかわる生体計測技術
が研究・開発されている2) 4). そのなかで, 瞬目, 眼 球運動，表情など顔に関する挙動は，人間の状態や意 図を把握するための重要な情報を含んでいることか ら, 最近多くの報告がなされている5)6.

瞬目については，映像分野で立体画像の効果を分析 した研究7), 福祉分野で身体障害者の意志伝達の補助 に適用した研究8), $\mathrm{OA}$ 分野で視覚負担の新しい他覚 的評価法を目指した研究 ${ }^{9)}$, あるいは基礎的な分野と して認知過程を探る心理実験10)など幅広く検討が進

キーワード : 自動車, 安全, 居眠り, 覚醒度 (覚醒水準), 瞬目 (まばたき), 画像処理

1995 年 5 月 19 日, 電子情報通信学会パターン認識・理解研究会で発表

1996 年 6 月 17 日受付, 1996 年 8 月 27 日再受付

$\dagger$ 株式会社豊田中央研究所 (T 480-11 愛知県愛知郡長久手町大字長湫字横道 41-1, TEL 0561-62-6111)

$\dagger$ Toyota Central R\&D Labs., Inc. (Nagakute, Aichi 480-11, Japan) 
められている，自動車分野では，瞬目は運転者の覚醒 や疲労の指標として期待されている.

近年, 高速道路などの整備が進み, 運転者にとって 長時間運転や単調な走行環境下での運転が増えるにつ れて, 居眠り運転による事故が重大な問題となってき ている．安全向上のため, 運転者の居眠りおよびその 前段階である覚醒度の低下を検知するシステムが強く 望まれている11122．

居眠りや覚醒度低下を検知する主な方法として, 脳

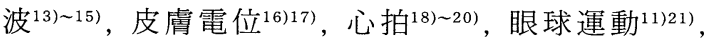

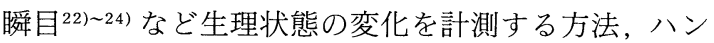
ドル,アクセルなど操作状態の変化を計測する方 法 $^{1122526)}$, 車速, 車両の蛇行など車両状態の変化を計 測する方法が知られている。このうち, 操作状態や車 両状態の変化を計測する方法は, 運転者の意志や運転 技量あるいは走行路の形状による影響が大きく，この 方法だけでは覚醒度低下を正確に検知できない場合が 多い。そこで，覚醒度を含む生体反応を直接計測でき る生理状態の計測に期待が寄せられている。そのなか でも瞬目を計測する方法は，他の方法に比べて，覚醒 度低下や居眠りの早期検知の可能性が高い方法として 有望視されている12226)27).

従来, 瞬目を計測する方法として, EOG（Electro -Oculogram, 眼球電図) 法, EMG (Electro-Myogram, 筋電図) 法, 磁気センサ法, 光学的測定法 （角膜反射量の変化による方法, 角膜と眼瞼との反射 量の変化による方法）が用いられてきた5)28). しか し, EOG 法や EMG 法では目の付近に電極を貼り付 けて計測すること, 磁気センサ法や光学的測定法では 素子を取り付けたゴーグルや眼鏡を装着して計測する ことから拘束感が強く, 自動車の運転者に適用するこ とは難しい。

自動車の運転者の瞬目を計測するには，非接触で拘 束感を与えない方法が不可欠である，最近では，離れ た場所からテレビカメラで運転者の顔を撮像し，その 画像から瞬目を計測する研究が行われてい

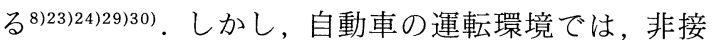
触・無拘束であるばかりでなく, 昼夜の照度変化を問 わず良好な顔の画像が得られること, 運転者の顔の個 人差によらずに信頼性良く計測できることが必要であ り,このような観点まで考慮した瞬目計測の報告は見 当たらない。また，計測した瞬目の情報から覚醒度を 推定するには，運転者ごとの覚醒度低下の特性の違い を考慮することも欠かせない。

本報告では，テレビカメラによる計測法により実際 の運転環境で瞬目を計測するため, 基本的に解決すべ
き 2 つ重要な課題, すなわち屋外での照度変化や外 乱光に強いこと, ならびに運転者の顔の個人差によら ないこと，を踏まえた瞬目計測法を提案する。また居 眠り検知への応用を考え，個人の特性の差を考慮した 覚醒度推定についても述べる。

\section{2. 運転環境での瞬目計測と居眠り検知の課題}

図 1 に, 瞬目計測による居眠り検知の概要を示す. まず，車の運転席に設置した撮像部（テレビカメラな ど）により運転者の顔画像を撮像する。その画像を処 理することにより運転者の瞬目を計測する，運転者の 正常時の瞬目に対する変化の割合から覚醒度を推定 し，居眠りしているか否かを検知する，居眠りと判定 した場合には運転者へ警報し，必要があれば刺激を与 えて覚醒させる．居眠り検知の一連の処理過程で，以 下の課題が考えられる.

瞬目計測では，まず夜間やトンネルなどの低照度時 に適用できる必要がある。 また, 昼間は, 太陽光の直 射などにより運転者の顔に車体の一部（サンバイザや ピラーなど）の影が生ずることが多い。この場合に は，顔の画像は影と直射部分とで “むら”になるため 良好な顔画像は得られず，瞬目を計測できない場合が 起こる，そこで，昼夜にわたり撮像でき，顔に対する 屋外の外乱光の影響を低減できる撮像法が必要にな る.

また，自動車では年齢や性別の異なった様々な運転 者に適用できることが重要である。しかし, 人間の顔 は目の付近の形態が異なり, 上瞼と眉毛の間の窪み方 や下瞼の皮膚の膨らみ具合の違いにより，撮像した画 像の濃淡が個人個人で異なり，信頼性良く瞬目を計測 できない場合がある，このような目の付近の濃淡の変 化は, 運転中の顔の向きや姿勢が変わると一層顕著に なる。そこで, 顔の個人差によらない画像処理法が重 要になる.

一方, 居眠りや覚醒度低下の判定では, 計測した瞬 目の情報と覚醒度との間の相関を把握すること, 更に その相関関係には個人の特性の差があることを踏まえ て，個人差を考慮した覚醒度推定が必要である。

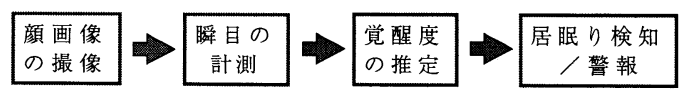

図 1 瞬目計測による居眠りの検知の概要 Overview of driver's drowsiness detection by blink measurement. 


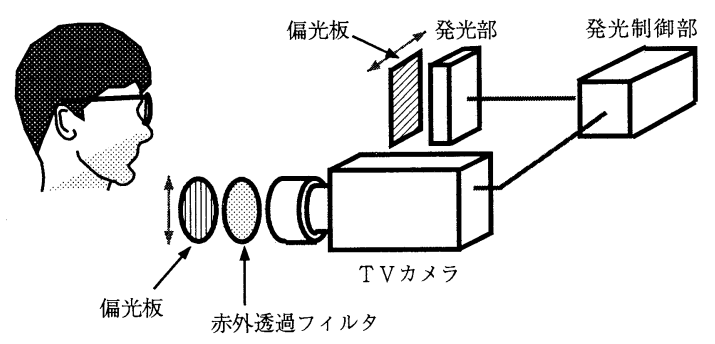

図 2 撮像部の構成

Configuration of imaging unit.

\section{3. 瞬目計測の方法}

\section{1 運転者の顔の撮像法}

まず, 低照度時に対応するために, 運転者の顔を照 明する光源を設ける．この光源は，運転者に眩しさを 与えないため赤外光とする.さらに，この照明光に対 する外乱光の影響を低減させるために，テレビカメラ を電子シャッ夕動作させ，これと同期させてパルス発 光する方式とする，パルス発光により，連続的に発光 させる場合よりもピーク時の発光強度を上げることが できる.テレビカメラでは発光期間中のみ露光するこ とになり, CCD に蓄積される電荷のうち外乱光に対 する照明光の比率を上げる効果がある.

図 2 は, 試作した撮像部の構成を示したものであ り, テレビカメラ, 発光部, 発光制御部, 偏光板から なる．テレビカメラは白黒の CCD カメラで, 赤外光 のみを透過するフィル夕を備えている. 発光部は, CCD の分光感度を考慮し, 中心発光波長が $850 \mathrm{~nm}$ の赤外 LED (8 行 8 列, 計 64 個) を用い, 運転者の 顔の撮像に必要な光量を確保している.ただし, 発光 強度（放射輝度值）は, 電子シャッ夕速度 $1 / 4000$ 秒, 発光時ピーク電流 $820 \mathrm{~mA}$ のとき $3.83 \times 10^{4} \mathrm{~W} \cdot \mathrm{m}^{-2}$. $\mathrm{sr}^{-1}$ であり, 眼球への赤外光照射の安全基準（JIS C 6802-1991準拠の最大許容露光量 ${ }^{31)} 8.53 \times 10^{5} \mathrm{~W}$ ・ $\mathrm{m}^{-2} \cdot \mathrm{Sr}^{-1}$ ) を考慮して決めている. 発光制御部では, テレビカメラの電子シャッタに同期してパルス発光さ せるための制御を行う。また，偏光板は眼鏡を掛けた 運転者の場合に発光部が眼鏡レンズで正反射して映る ことを避けるため設けており, 偏光面を直交させた偏 光板を発光部とテレビカメラの前面に備えることで正 反射成分の低減を図っている。サングラスや色付きメ ガネでは, 近赤外領域での分光透過率の測定から, $90 \%$ 前後の透過率を示すものがあり, 本撮像部で問題 なく撮像できるものがあることを確認している.

この撮像部の効果を確認するため, 実際に自動車に
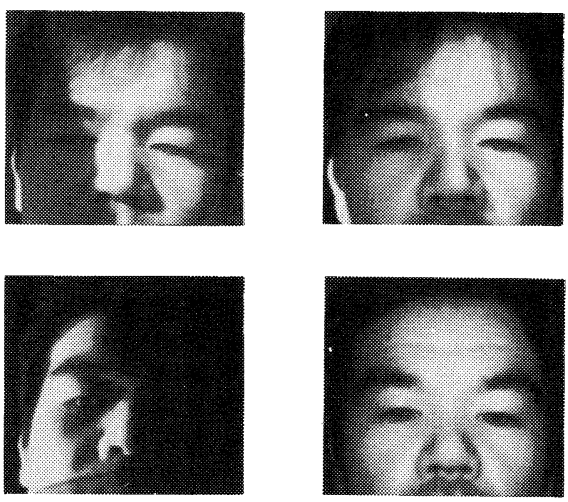

(a ) 昼間と夜間での効果

$<$ 偏光板無い場合 $>$

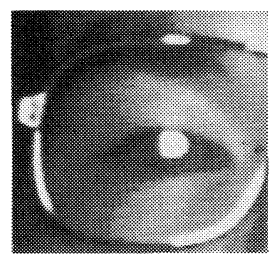

（b）眼鏡に対する効果

図 3 本撮像部による顔画像

An example of facial images by imaging unit.

撮像部を設置し，様々な運転環境で運転者の顔を撮像 した. 図 3 にその顔画像の一例を示す. 図 3(a)は, 昼間（屋外照度が約 $800001 \mathrm{~lx}$ ）太陽光が逆光となって 顔に直射し車体のピラーが影になった場合と, 夜間横 から他車両のヘッドランプで顔を照らされた場合のそ れぞれについて, 光源を設けずに撮像した場合に対す る本撮像部の場合の効果を示したものである．夜間の 場合には，光源がないとへッドランプで照らされた部 分（顔の左半面）と照らされていない部分（顔の右半 面）との濃度差は著しいが, 本撮像部を用いると濃度 むらのない顔画像が得られる。また昼間の場合，太陽 光直射の部分と車体の影の部分の画像の濃度比は, 光 源がない場合（テレビカメラの電子シャッ夕速度：1/ 60 秒) は平均 8.6 , 本撮像部（電子シャッ夕速度：1/ 4000 秒, 赤外 LED の発光強度 : $3.83 \times 10^{4} \mathrm{~W} \cdot \mathrm{m}^{-2}$ ・ $\left.\mathrm{sr}^{-1}\right)$ では平均 2.6 であり, 本撮像部による画像の方 が影の影響による濃度むらは著しく低減されている。 本撮像部により, 昼夜を問わず運転環境の照度変化や 外乱光がある場合でも良好な顔画像が得られることが わかる. 
図 3(b)は, 眼鏡を掛けた運転者について, 偏光板 を設けずに撮像した場合に対する本撮像部の効果を示 したものである．本撮像部では，眼鏡レンズに正反射 の光が映ることなく良好な顔画像が得られている.

\section{2 瞬目計測のための画像処理法}

図 4 に赤外光による目の画像を示す. 左側の図は実 際の画像の一例であり，右側は模式的に示した図であ る.人間の黒目は絞りに相当する虹彩と開口部の瞳孔 からなっている. 可視光による画像では, 両者ともほ ぼ一様に黒く見えるが, 赤外光による画像では, 虹彩 での反射率が高いため瞳孔だけが暗く, 虹彩は眼球の 白目より若干暗い程度の明るさである。上下瞼の皮膚 は虹彩や白目より明るくなる。

図 5 は, 瞬目計測の処理の流れを示したものであ る。瞬目計測では, 目の開き度合いを表す值（以下， 目の開度と呼ぶ）として, 眼球の黒目と白目の露出面

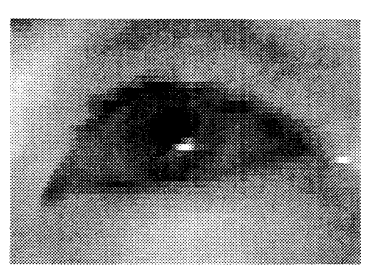

〈画像の一例〉

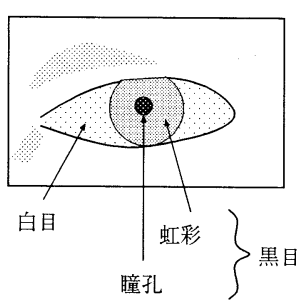

〈模式的な図〉
図 4 赤外光による目の画像

Eye image using infrared light source.
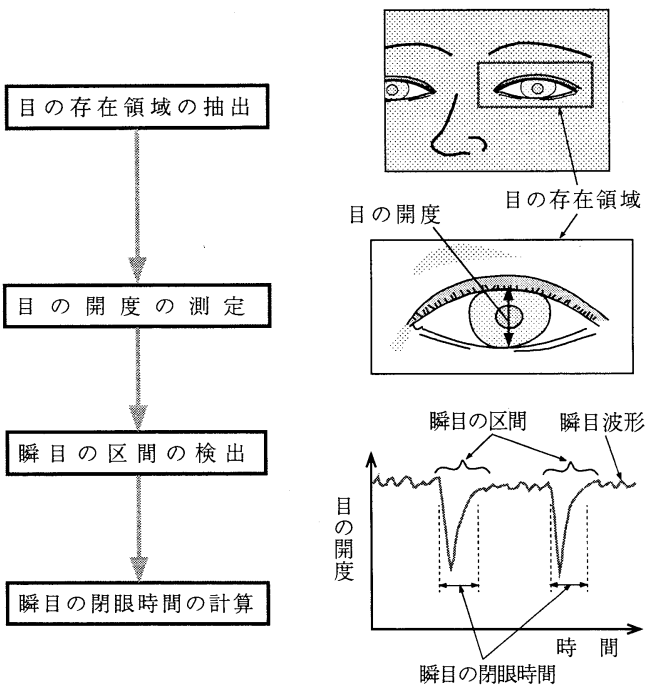

図 5 瞬目計測の流れ

Flow chart of blink measurement.
積を計測する方法と, 上下瞼の間隔を計測する方法が あるが, 本方法では後者を計測する。まず, 目の存在 領域(目を含む小領域)を 80 画素 $\times 25$ 画素程度の大き さ (目の開眼時の大きさで平均 50 画素 $\times 10$ 画素) で抽 出する。この大きさは, 運転者の顔の動きを考慮し, 顔全体がテレビカメラの画角に収まるように設定した 值である。その画像から目の開度を測定する。1 フレ ームごとに目の存在領域を抽出し, それぞれのフレー ムについて目の開度を測定することにより，目の開度 の時間変化を示す瞬目波形を作成する。瞬目の区間 は, 瞬目波形において目の開度がいったん小さくなり 再び元の大きさに戻る下向きのパルス状の部分として 検出する。パルス状の部分を瞬目と判断する基準は, 瞬目の微分波形において, 負の極小点と正の極大点と の差が 15 画素以上ある部分としている.瞬目の区間 ごとに，1回の瞬目に要する時間（以下, 瞬目の閉眼 時間あるいは単に閉眼時間と呼ぶ）を計算する。運転 者の体や顔の動きに対しては, 目がテレビカメラの画 面から外れない範囲では, 上下や左右に動いても問題 なく瞬目を計測できる。ただし, 顔の向きが変わる場 合には, 上下と左右に約 $10^{\circ}$ の回転の範囲で計測でき る程度である。この瞬目計測では, 目の存在領域は最 初の 1 フレーム目だけは人手により大まかな位置を指 定し, 次のフレームからは前フレームで検出した目の 概略の位置をもとにして自動的に抽出する方法とす る. 実際の居眠り検知を想定すると, 最初運転者に正 面を向いて自発的な瞬目を行ってもらい, 開眼時と閉 眼時の顔画像の差分から目の存在領域を特定する方法 などが考えられる。

図 5 の瞬目計測のうち, 顔の個人差の影響を受けや すいのは主として目の開度の測定である。目の開度 は, 上瞼と眼球の境界線および下瞼と眼球の境界線を 検出し, 両方の境界線の間隔として測定する.個々人 の目の付近の形態の違い, 特に上瞼と眉毛の間の篞み 方の違いや下瞼の皮膚の膨らみ具合の違いにより, 上 下瞼と眼球との境界線以外に影が生ずる場合には，そ れらの影を境界線と誤り, 目の開度を正確に求めるこ とができない，極端な場合には，閉眼状態でも開眼状 態と誤ることもあり, 顔の個人差を考慮した目の開度 の測定は不可欠である.

図 6 に, 個人差を考慮した目の開度測定の処理の流 れを示す。まず, 縦方向の断面を端から等間隔に画像 全体にわたって設定し, 各断面で上瞼と眼球の境界点 および下瞼と眼球の境界点（図の黒丸）を検出する. この境界点は, 断面の濃度分布において微分值を求 め, 濃度変化の大きな点でかつ濃度変化の符号が反対 

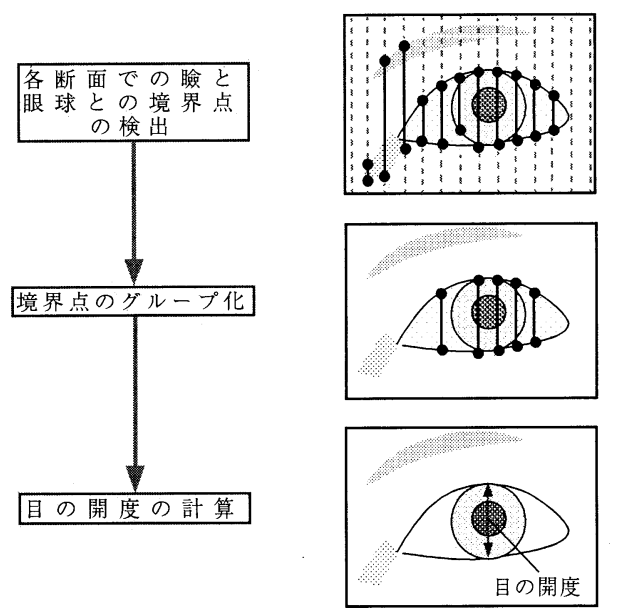

図 6 目の開度測定の流れ

Flow chart of measurement of eye opening degree.

の点（明から暗に変化する点と暗から明に変化する 点）を組にして検出する. 各断面の境界点の組のなか には，影の影響などで正しい境界点の位置を示してい ないものも含まれる。 そこで, 各断面の境界点の組の うち，それぞれの境界点の位置および境界点間の距離 が似通っているものを選んでグループ化する．そのう ちの中央付近の数本について境界点間の距離の平均值 を計算し, 目の開度とする。この方法は, 画像を 2 值 化せず 1 次元の簡単な濃淡処理を画像全体に施すた め, 個人差による様々な画像の濃淡の変化に強い方法 と考えられる。

\section{4. 瞬目計測の評価実験}

\section{1 方 法}

考案した瞬目計測法の顔の個人差への耐性を調べる ため, 以下の実験を行った。被験者は, 目の付近の形 態が異なる 20〜 50 代の男性 8 名（各年代 2 名ずつ） とした。実験方法は，まず実験室内に配置した自動車 のカットボディを用い, ドライバの視点から俯角 $10^{\circ}$ 程度の位置に本撮像部を設置した。この撮像部によ り, 運転席に座った被験者の顔を撮像し, その顔画像 をビデオレコーダに記録した。このとき，運転中の顔 の向きの変化を考慮するため, 前方正面抢よび正面か ら上下と左右にそれぞれ $15^{\circ}$ の範囲内で，できるだけ 眼球を動かさず顔の向きだけで 50 ずつ見る方向を変 えてもらった。具体的には，前方のスクリーン上に， 見る方向を示すマークを映し, 約 3 分間ずつ注視して もらった。

次に, 記録したビデオを人間が目視しながら，1人

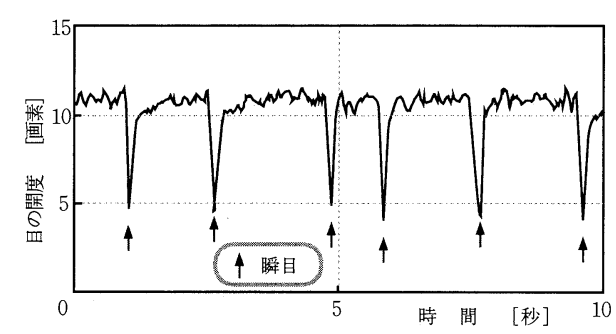

（a）顔が前方正面を向いている場合

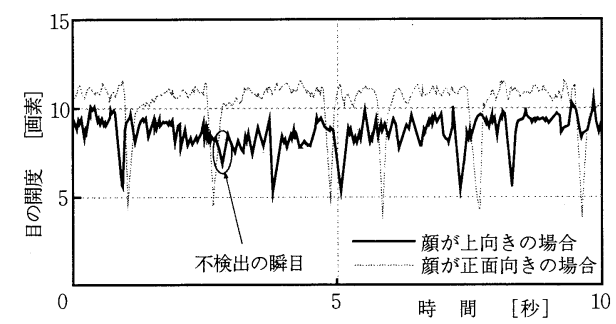

（b）顔が正面より上向きの場合

図 7 . 瞬目波形の例

An example of measurement of blinking waveforms.

の被験者あたり，1つの注視方向ごとに，10 回分の瞬 目を含むビデオの区間を抽出した。被験者 8 人につい て，すべての注視方向の瞬目の数を合計すると 1040 回の瞬目となる.

このビデオの顔画像を用いて本計測方法で瞬目の区 間を検出し，検出率を調べた，検出できなかった場合 は，瞬目があったのに検出できなかった場合（以下， 不検出と呼ぶ）と，瞬目がないのに瞬目の区間と誤つ て検出した場合（以下, 誤検出と呼ぶ）に分けられ, 検出率とは, 全体の瞬目回数に対する正しく検出でき た割合とする。

瞬目計測の画像処理は, 記録された顔画像を 1 フレ ームごとにコマ送りし，すべてソフトウェア処理によ り行った。処理時間は, 1 フレーム約 1.2 秒（うち, ビデオレコーダのコマ送りなどの制御は 0.3 秒程度) であった。

\section{2 結 果}

実験の結果をまとめると, 合計 1040 回の瞬目に対 して, 正しく検出できた瞬目は 1004 回（不検出：36 回, 誤検出：11 回）で, 検出率は $96.5 \%$ あっった. 図 7 に実際の瞬目波形の例を示す．同図（a）は顔が前 方正面を向いている場合であり, 同図 ( b ) は正面より $15^{\circ}$ 上向きの場合である, 不検出の主な原因は, 図 7(b)の例のように，顔を上向きにしたときに多い. これは, 顔が正面を向いているときよりテレビカメラ からみて開眼時の目の開度が小さく撮像され,さらに 
閉眼時の目の開度が大きい場合（閉眼しているにもか かわらず，画像処理で目の開度が大きめに計測される 場合，ならびに実際の瞬目が完全な閉眼に至らない場 合）に起こる。また，不検出の他の原因として，目が 完全な開眼状態にならず半開きの場合にも開眼時と閉 眼時の目の開度の差が少なくなり, 瞬目と判定しづら い場合が生ずる。さらに速い瞬目に対し，通常のテレ ビカメラのフレームレート (33 ms)ではサンプリング 間隔が粗すぎて不検出となる場合も起こる。一方，誤 検出の主な原因は，顔の向きにより上下瞼と眼球との 境界線の濃度の変化が少なくなり, 目の開度が正確に 測定できない場合である。これらについては今後の課 題である. 以上，限られた被験者での実験ではある が，本方法により基本的には顔の個人差に依らず瞬目 計測が行えることが確認された。

\section{5. 居眠り検知への応用}

\section{1 瞬目の閉眼時間と覚醒度との関係}

居眠り検知のため運転者の覚醒度を推定するには， 瞬目計測により得られた閉眼時間と覚醒度との関係を 把握するとともに，その関係が個人の特性の違いによ ってどの程度変化するかを知る必要がある，閉眼時間 と覚醒度との関係を定量的に把握するため, 次のよう な実験を行った。

図 8 に実験システムの構成を示す。このシステム は, ドライビングシミュレータ, 瞬目計測のための本 撮像部と画像処理部，ならびに顔画像を記録するビデ オレコーダなどからなる。ドライビングシミュレータ は, 液晶プロジェクタにより運転席前方のスクリーン に走行路面の映像を映し, 被験者の運転操作に連動し てその映像が変わるようにしたもので, 実際の自動車 の運転を模擬的に行えるようにした装置である.

実験では， 3 車線の直線道路のうち中央車線を一定

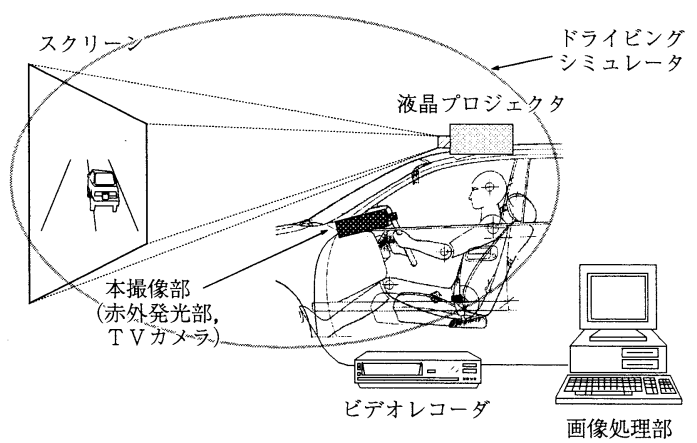

図 8 実験システムの構成 Configuration of experimental system.
の速度（100 km/h）でハンドル操作だけで走行する ように被験者に指示した。単調な運転のため, 時間経 過とともに覚醒度が低下して居眠りし, 最終的には運 転不能となる。運転不能とは, 車両の蛇行が著しくな り，走行車線を逸脱する場合である．

計測するデータは，生理的な指標として瞬目の閉眼 時間，運転作業の指標として車両の横偏位（車両の走 行軌跡から求めた横方向の蛇行量), 心理的な指標と して眠気の度合いとした。眠気の度合いは，4段階 （眠くない，やや眠い，かなり眠い，運転不能）の自 己申告とした。被験者は 30～40 代の男性 5 名であ る。

図 9 は，1人の被験者について実験開始から覚醒度 低下に伴う瞬目の閉眼時間, 車両の横偏位を示したも のである.図 9 の左のグラフは，時間経過に対する閉 眼時間と横偏位で，それぞれ 1 分単位の平均值（平均 閉眼時間と平均横偏位）で表している。時間経過とと もに覚醒度が低下していることは，自己申告で確認し た. 実験開始後 60 分付近でグラフが途切れているの は, その時点で隣接車線にはみ出るほどの蛇行運転が 目立ち，運転不能の状態に達したことを示している． 覚醒度低下に伴い, 平均閉眼時間と平均横偏位が共に 増加して扔り，運転不能な状態では平均閉眼時間は実 験開始の正常時に比べて約 2 倍になっている. 図 9 の 右のグラフは, 平均閉眼時間と平均横偏位の散布図を 示したもので, 回帰直線を求めると両者には良い相関 （相関係数 $0.84 ）$ があることがわかる.

被験者 5 名についての実験結果は, いずれも図 9 と 同じ傾向を示し，平均閉眼時間と平均横偏位の散布図 から求めた回帰直線の相関は高かった（相関係数： 0.72〜0.95).ただし, 回帰直線の傾きは被験者ごと の覚醒度低下の特性の違いを反映し, 異なった傾きを 示した。走行車線を逸脱し運転不能になるほどの覚醒 度低下の状態では, 平均横偏位の值は $0.8 \sim 1.0 \mathrm{~m}$ に なり，そのときの平均閉眼時間の正常時に対する比率 は 1.5 約 3 倍と, 被験者ごとに異なった。この結
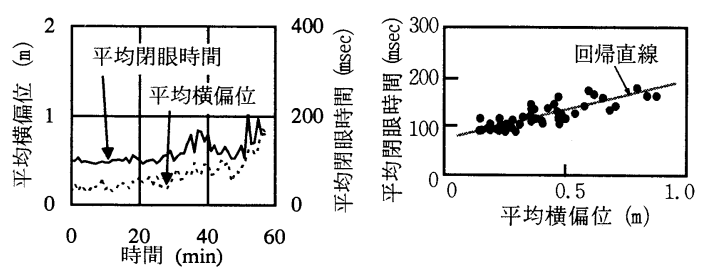

図 9 瞬目の閉眼時間と覚醒度低下の実験 Blinking duration change according to arousal level deterioration. 
果, 平均閉眼時間により覚醒度低下の度合いを個人ご とに推定できる見通しが得られたが，平均閉眼時間の 正常時に対する比率がどの程度増加したら居眠りと判 定できるかは, 個人ごとに決めておく必要があること がわかった。

\section{2 覚醒度の推定}

個人の特性まで考慮した覚醒度推定は一般には難し く, 本来は瞬目の閉眼時間だけではなく, 瞬目から得 られる他の情報や瞬目以外の様々な計測デー夕を併せ て推定する必要があると考えられるが，ここでは単純 化のため, 瞬目の閉眼時間だけを用いて個人ごとの特 性にできるだけ適応した覚醒度推定の可能性を探るこ とにする. 図 9 に示した実験結果から, 高速道路のよ うに単調な運転に限れば, 個人ごとの覚醒度低下の特 性は, 平均閉眼時間と平均横偏位との相関を示す回帰 直線の傾きに反映される.しかし, 回帰直線の傾きを 求めるため, 事前に実験などによって計測しておくこ とは実用的ではない。 そこで, 運転時に閉眼時間と横 偏位を同時に計測し，運転開始時からその時点までに 得られたデー夕により回帰直線の傾きを求め, 個人の 特性を得ることにする。この方法の前提として, 運転 開始時は被験者の覚醒度は高く正常な状態であるこ と, ならびに平均横偏位 $0.8 \mathrm{~m}$ 程度を走行車線逸脱 で運転不能な状態と見なすこととする。

図 10 に, 覚醒度低下の特性の個人差に対応する方 式を示す。時間の経過とともに, 正常 (覚醒状態), 少し覚醒度低下, 覚醒度低下と進むものとする. 正常 (覚醒状態)では, 平均閉眼時間と平均横偏位は小さ く, 両者の関係を示す値は左下に集中するため, 回帰 直線の傾きは一般に小さく, また一定の值に落ち着か ないと予想される，覚醒度が低下寸るにつれて，平均 閉眼時間と平均横偏位は大きくなり, 両者の関係を示 す値は徐々に右上に出現し, 回帰直線の傾きは増加す る. 覚醒度がかなり低下寸ると, 回帰直線の傾きは増 加から一定の值に落ち着き, この時点で個人の特性が 反映された有意な回帰直線が得られると考えられる。

図 11 は, 図 10 の個人差対応方式の有効性を示した ものである。この図は, 図 9 に示した覚醒度低下の実 験のデータ (平均閉眼時間と平均横偏位)を用いて, そ の時点での回㷌直線の傾きを 1 分ごとに計算したもの である. 平均閉眼時間は実験開始時に対する比を示 す. 回帰直線の傾きは時間経過につれて増加するが, 実験開始後 45 分ほどで増加は止まり安定する。これ は, 覚醒度低下により運転不能に陥る実験開始後 60 分以前に, 被験者の特性が得られたことを意味する. この方式は, 個人ごとの事前の登録や実験は不要であ

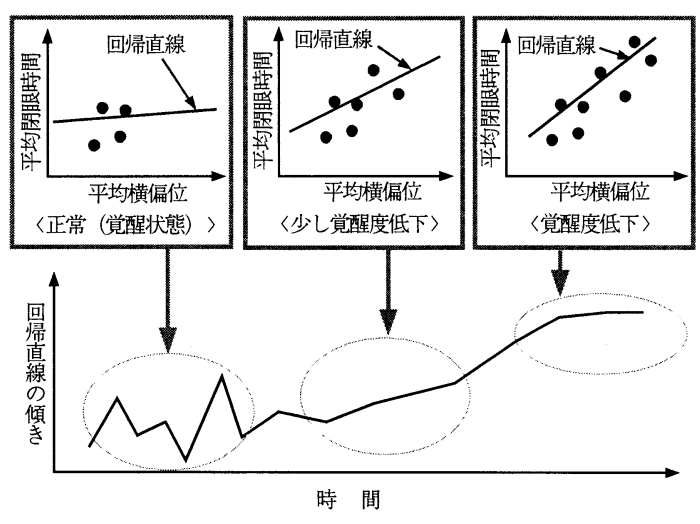

図 10 覚醒度低下の個人差対応方式 Method for individual characteristic of arousal level deterioration.

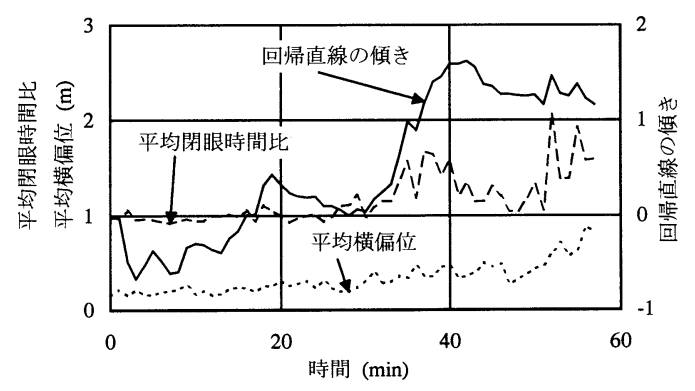

図 11 個人差対応方式の実験の一例

Experiment in method for individual characteristic.

り, 各個人の経時変化にも対応できる利点がある．

以上は単調な運転での実験であり，しかも瞬目の閉 眼時間と車両の横偏位だけを用いた単純な方法で, 必 ずしも運転者の覚醒度の低下を正確に推定できる方法 とはいえないが, 個人ごとに居眠り検知の大まかな目 安を得られる点で有効と考えられる。

\section{6. むすび}

自動車の運転者の居眠りあるいは覚醒度低下を信頼 性良く検知するため, テレビカメラで運転者の顔を撮 像した画像から非接触かつ無拘束に瞬目を計測する方 法を開発し, 居眠り検知のための覚醒度推定を検討し た。本報告では, 昼夜にわたり屋外での照度変化や外 乱光の影響に強く, 運転者の顔の個人差によらない瞬 目計測法, ならびに個人の特性の違いを考慮した覚醒 度推定について述べた。

瞬目計測では, 運転者の顔を赤外光で照明し, 照明 光に対する外乱光の影響を低減させるため, テレビカ メラの電子シャッ夕動作に同期させてパルス発光する 撮像方法を開発した。また, 顔の個人差に強い目の開 
度の測定により, 瞬目の閉眼時間を求める方法を提案 した，覚醒度推定では, 運転時に個人の特性を示す回 帰直線を刻々と更新し, 個人差に対応する方式を検討 した。

本論文では, 比較的明瞭な瞬目（開眼時と閉眼時の 目の開度の差が一定の值以上あるもの）を対象とし， ある程度顔の動きも考慮して顔の個人差によらずに瞬 目を計測する方法を示した。しかし，運転中の様々な 顔の動きを許容して正確に瞬目を計測するには, 課題 が残されていると考える。また, 覚醒度低下の指標と しては, 曖昧な瞬目（開眼時または閉眼時の目が半開 きの場合）の計測も課題である. 今後, 曖昧な瞬目を 含め, 瞬目の他の情報（瞬目の間隔や出現頻度など）, ならびに他の計測方法から得られる様々な情報につい て, 覚醒度低下との相関という観点からさらに検討す る必要があり, 多数の被験者を用いた実験や実車に近 い状況での検討が重要と考える。

\section{〔参 考 文 献〕}

1）遠藤： “ヒューマンインタフェースの視点と展望”,テレビ誌, 48, 8, pp. 955-959 (1994)

2) 漆原：“「人間感覚計測応用技術」プロジェクトの意義（人 にやさしい技術への転換)”，日本の科学と技術 (春号)， $\mathbf{3 6}$, 276, pp. 20-27 (1995)

3）吉川, 栗山, 加藤: “人間感覚計測応用技術一基礎研究からプ ロジェクト研究への発展”, システム/制御/情報, $38,7, \mathrm{pp}$. 356-364 (1994)

4）高野: “生体情報総合計測システムの開発と応用”, システ 么/制御/情報, 38, 7, pp. 375-382（1994）

5）星野：“注意と瞬目”, テレビ誌, 50, 4, pp. 436-442 (1996)

6) 山田: “最近の眼球運動の研究動向”, 信学技報, MBE 95132, NC 95-90, pp. 145-152 (1995)

7) 石山, 山田, 磯野: “ハイビジョン立体画像観察時の瞬目に関 する分析”, テレビ誌, 49, 8, pp. 1032-1041 (1995)

8）加納, 井上, 小林, 川上, 井上：“ニューラルネットワークによ る「まばたき」の検出”, 電学論 (C)， $\mathbf{1 1 5} ， 3 ，$ pp. 367372 (1995)

9）星野: “視覚負担推定のための自発性瞬目の開瞼時間の解 析”, テレビ誌, 48, 6, pp. 702-707 (1994)

10)田辺, 杉山： “心理実験のための瞬目の自動抽出法”, 信学論 (D-II)， J76-D-II, 5, pp. 959-966 (1993)

11）世古: “ドライバの居眠り状態を検出する技術の現状”, 自動 車技術, 38, 5, pp. 547-554（1984）

12）黑木, 麻生: “いね㸚り運転警報装置の一試案”, 自動車技術 会学術講演会前刷集, No. 772 B 57, pp. 393-396 (1977)

13）深沢，他：“脳波などを用いた自動車運転者の覚醒度の評価 法について”, 日本人間工学会第 20 回大会論文集, pp. 256257 (1979)

14）岸, 岡本, 阿部, 石橋, 石田: “ドライバの覚醒度評価手法につ いて”, 自動車技術, 46, 9, pp. 17-22（1992）

15）黒田, 吉田: “脳波ゆらぎから覚醒度を推定するニューラル ネットの作成”, 自動車技術, 49, 9, pp. 91-96（1995）

16）西村, 小坂, 常光, 吉沢, 南雲: “皮膚電位水準による自動車運 転時の覚醒水準評価の試み $\mathrm{I}$ 一路上運転時の皮膚電位変化 一”, 人間工学, 23,2 (1987)

17）览玉, 伊藤, 亀井, 中島, 小野, 坂口, 大橋 : “皮膚電位を用いた 覚醒度検出装置の開発”, 自動車技術会学術講演会前刷集, 912 (1991)
18) M. R. Volowetal: "The Heart Rate Variability Correlates of Spontaneous Drowsiness Onset”, SAE Paper 730124

19）渥美：“心拍計測によるドライバの意識状態評価一自律神経 指標を用いた緊張感と眠気の計測—”, 自動車技術会学術講 演会前刷集, 946（1991）

20）川上, 神谷, 濱谷：“運転者の覚醒度低下”, 自動車技術, 46, 9, pp. 29-33 (1992)

21）山本, 樋口: “大型トラックの長時間運転時の覚醒度評価の 検討”, 自動車技術, 46, 9, pp. 23-28 (1992)

22）保坂, 渡辺: “まばたき発生パターンを指標とした覚醒水準 評価の一方法”, 人間工学, 19, 3, pp. 161-167 (1983)

23）金田, 上野, 月野: “居眠り検出技術に関する研究”, 自動車技 術会学術講演会前刷集, 941, No. 9432570 (1994)

24）片原, 青木：“ドライバーのまどろみ検出を目的とした顔画 像からの上まぶたの検出と動き追跡”, 電学技報（道路交通 研究会), RTA-96-4, pp. 27-36 (1996)

25）福田, 阿久津, 青木: “修正操舵認識による意識低下推定法の 検討”, 自動車技術会学術講演会前刷集, 941 , No. 9432589 (1994)

26）石原, 福井: “自動車運転中の覚醒度の検出”, 自動車技術会 学術講演会前刷集, 951, No. 9534405 (1995)

27）西村, 小坂, 常光, 吉沢, 南雲: “皮膚電位水準による自動車運 転時の党醒水準評価の試み II 一諸生理量の比較—”, 人間工 学, 23, 2 (1987)

28）吉岡, 宮田, 大須賀：“まばたき波形を利用した傾眠防止：I . 磁気センサ法 (MAG 法) による波形計測”, 人間工学, 19, 特別号, B・2-6, pp. 182-183 (1987)

29）田辺, 杉山：“色度と明度情報を用いた瞬目抽出法の提案”, 信学論 (D-II), J77-D-II, 2, pp. 470-472 (1994)

30）渡辺, 全, 大島: “時空間画像を用いた瞬目波形自動抽出の試 み”, 1994 信学秋大, D-352（1994）

31）通産省工業技術院，光産業技術振興協会：“レーザ安全ガイ ドブック (改訂版) ”, 新技術コミュニケーションズ (1992)

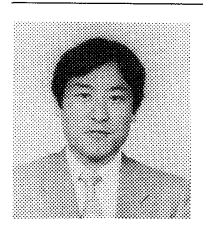

势野倫明 1982 年, 名古屋大学大学院 工学研究科修士課程修了. 同年, (株) 豊田中 央研究所入社. 画像によるパターン認識, 三 次元計測・検査, 車載ディスプレイの表示と 視認性など自動車におけるヒューマンインタ フェースの研究と開発に従事. 現在, 同所画 像情報研究室所属. 工学博士. 正会員.

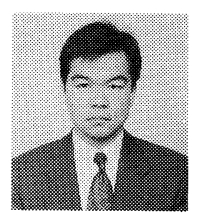

杉山唯山和彦 1985 年, 名古屋大学大学院 工学研究科修士課程修了。キヤノン (株) を経 て, 1990 年, (株) 豊田中央研究所入社. 以 来, 自律走行車の視覚および自動車における ヒューマンインタフェースに関する研究と開 発に従事. 現在, 同所画像情報研究室所属.

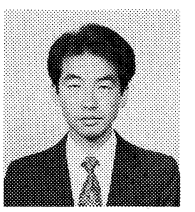

永野守倫 1990 年, 東北大学大学院工 学研究科修士課程修了. 同年, (株) 豊田中央 研究所入社. 以来, 自動車におけるヒューマ ンインタフェース，ロボット視覚に関する研 究と開発に従事. 現在, 同所画像情報研究室 所属.

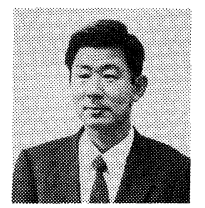

山本新 1965 年, 岐皁大学工学部電 気学科卒業. 同年, (株)豊田中央研究所入 社. 三次元画像計測・認識, 車載視覚センサ および車載ディスプレイの視認性など自動車 におけるヒューマンインタフェースの研究と 開発に従事. 現在, 同所画像情報研究室室 長. 主席研究員. 豊田工業大学大学院工学研 究科客員教授兼任. 工学博士. 正会員. 